\title{
Shuni Virus in Cases of Neurologic Disease in Humans, South Africa
}

\author{
Thopisang P. Motlou, Marietjie Venter
}

We describe Shuni virus (SHUV) detection in human neurologic disease cases in South Africa. SHUV RNA was identified in $5 \%$ of cerebrospinal fluid specimens collected during the arbovirus season from public sector hospitals. This finding suggests that SHUV may be a previously unrecognized cause of human neurologic infections in Africa.

\begin{abstract}
rthropod-borne viruses (arboviruses) warrant atAtention in the global health landscape because of their potential to cause widespread epidemics worldwide (1). Epizootics in animals may signal an increase in virus activity and predict potential missed human outbreaks, as shown for West Nile virus neurologic infections in horses (2-4) and humans (5) and Rift Valley fever associated with abortion storms in livestock and cases of febrile and neurologic disease (6) and miscarriages in humans $(7,8)$.

Arboviruses of African origin are largely responsible for the recent expansion in geographic range of emerging viruses worldwide. These viruses have been associated with human illness and death in new regions in recent years but remain underreported in Africa (9). Cases of neurologic arbovirus infections are thought to be underreported in humans in South Africa, with $\approx 3 \%$ of cerebrospinal fluid (CSF) samples of neurologic infections in humans testing positive for West Nile virus (7). This raised the question as to whether other neglected zoonotic arboviruses are circulating in Africa that may potentially cause future outbreaks in new regions (10).

Shuni virus (SHUV) has recently been described as a cause of neurologic infections in horses in South Africa (11) and emerged as a cause of neurologic infections and birth defects in livestock in Israel (12). Before this study, there had been only 1 confirmed human SHUV case since 1966 (13). We used real-time reverse transcription PCR (rRT-PCR) to investigate whether SHUV is associated with unsolved neurologic cases in humans in South Africa by screening
\end{abstract}

Author affiliation: University of Pretoria, Pretoria, South Africa

DOI: https://doi.org/10.3201/eid2702.191551 archived CSF samples collected for viral diagnosis from hospitalized patients during the arbovirus season in January-May 2017.

\section{The Study}

We obtained archived CSF specimens from public sector hospitals across Gauteng Province, South Africa, through the National Health Laboratory Service, Tshwane Academic division, from patients who had neurologic signs and symptoms during January-May 2017. We grouped the CSF specimens into 4 categories based on age: age group 1 was children $(<1-12$ years of age); age group 2, adolescents (13-18 years of age); age group 3, adults (19-59 years of age); and age group 4 , senior adults ( $\geq 60$ years of age). SHUV-positive cases were determined by an Orthobunyavirus genus-specific RT-PCR and confirmed using Sanger sequencing and phylogenetic analysis.

We extracted RNA from the CSF samples using the QIAamp Viral RNA Kit (QIAGEN, https:/ / www.qiagen.com). We performed an Orthobunyavirus genus-specific RT-PCR using the Agpath-ID One Step RT-PCR (Thermo Fisher Scientific, https:/ / www.thermofisher.com) with primers designed to amplify a 155-bp fragment of the nucleocapsid gene of the small (S) segment of orthobunyaviruses (14). We analyzed the sequences using the BioEdit DNA sequence alignment editor v7.0 5.3 software (15) and Blast search analysis (http://blast.ncbi.nlm.nih.gov/ Blast.cgi). We performed phylogenetic analysis using maximum-likelihood analysis (MEGA X, http:/ / www.megasoftware.net) as confirmation that the amplicons represent SHUV (Figure, panel A). A larger region of the $S$ segment $(\approx 460 \mathrm{bp}$ ) could be sequenced for only 1 of the positive samples (ZRUH131/17, GenBank accession no. MN937197) (Figure, panel B) because of low viral RNA concentration and sample volume in the other CSF samples.

A total of 7 of 130 (5.4\%) CSF samples tested positive with an Orthobunyavirus rRT-PCR targeting the S segment and were confirmed by DNA sequencing to represent SHUV (Figure, panel A). A longer region 
was obtained for a CSF sample taken from a patient who was confirmed to have had neurologic diseases (meningitis, encephalitis, and seizures) with a clinical diagnosis of TB meningitis. Apart from neurological signs, additional clinical diagnoses in other patients

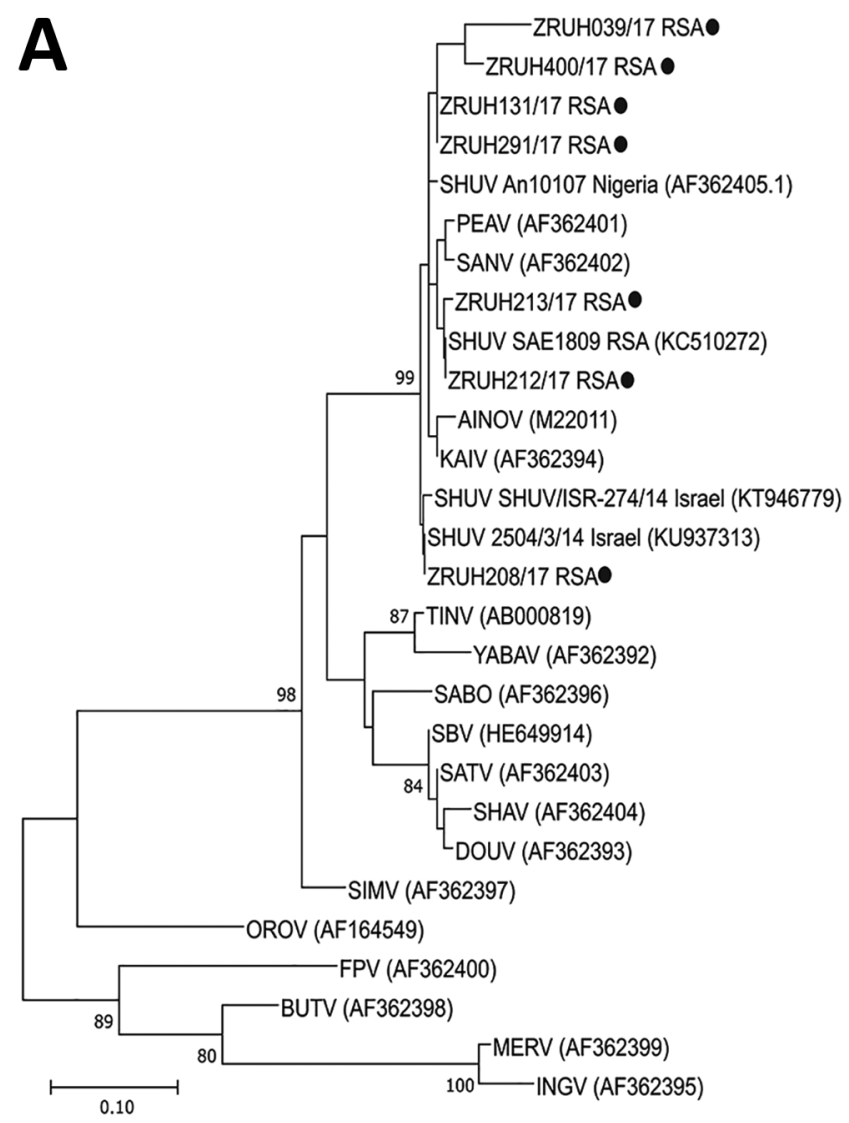

included respiratory diseases (tuberculosis, upper respiratory tract infection, and pneumonia), gastrointestinal diseases, vomiting, and hydrops fetalis (Table 1). Only 3 patients' HIV status was recorded, of which 1 patient's mother was confirmed to be HIV positive and

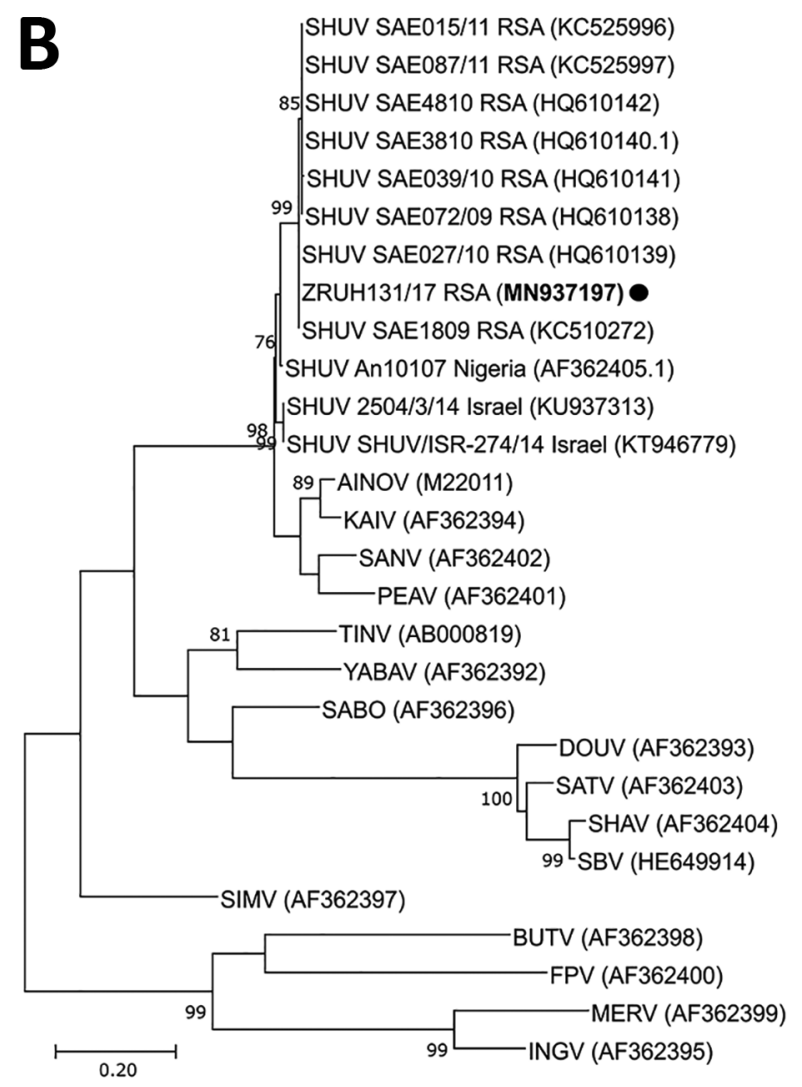

Figure. A) Phylogenetic confirmation that the orthobunyavirus small (S) segment specific reverse transcription PCR (14) positive products identified in this study clustered with SHUV strains. The 155-bp sequence of the nucleocapsid gene of the S segment of the human clinical isolates were aligned to SHUV strains previously identified in animals and other Orthobunyaviruses in the Simbu serogroup. The evolutionary history was inferred by using the maximum likelihood method and Kimura 2-parameter model. The tree with the highest log likelihood $(-1043.27)$ is shown. The percentage of trees in which the associated taxa clustered together is shown next to the branches. Initial tree(s) for the heuristic search were obtained automatically by applying neighbor-joining and BioNJ algorithms to a matrix of pairwise distances estimated using the maximum composite likelihood (MCL) approach and then selecting the topology with superior log likelihood value. A discrete gamma distribution was used to model evolutionary rate differences among sites ( 5 categories [ $+G$ parameter $=0.6884]$ ). This analysis involved 28 nt sequences. All positions containing gaps and missing data were eliminated (complete deletion option). There were a total of 151 positions in the final dataset. Evolutionary analyses were conducted in MEGAX (http://www.megasoftware.net). Black circles indicate the newly sequenced positive human samples (ZRUH208/17, ZRUH131/17, ZRUH219/17, ZRUH212/17, ZRUH213/17, ZRUH400/17, ZRUH039/17). B) Phylogenetic analysis of a human SHUV-positive case using a larger region of the S-segment amplified with SHUV-specific primers. The evolutionary history was inferred by using the maximum likelihood method and Tamura-Nei model. The tree with the highest log likelihood $(-3135.73)$ is shown. The percentage of trees in which the associated taxa clustered together is shown next to the branches. Initial tree(s) for the heuristic search were obtained automatically by applying neighbor-joining and BioNJ algorithms to a matrix of pairwise distances estimated using the MCL approach and then selecting the topology with superior log likelihood value. A discrete gamma distribution was used to model evolutionary rate differences among sites $(5$ categories $[+G$, parameter $=0.3230]$ ). This analysis involved $28 \mathrm{nt}$ sequences. All positions containing gaps and missing data were eliminated (complete deletion option). There were a total of 324 positions in the final dataset. Evolutionary analyses were conducted in MEGAX. Black circle indicates the newly sequenced positive human strain (ZRUH131/17, GenBank accession no. MN937197). Sequence data are available upon request; numbers in parentheses for related strains indicate GenBank accession numbers. Scale bars indicate nucleotide substitutions per site. AINOV, Aino virus; AKAV, Akabane virus; BUTV, Buttonwillow virus; DOUV, Douglas virus; FPV, Faceys Paddock virus; INGV, Ingwavuma virus; KAIV, Kaikalur virus; KAIRV, Kairi virus; MERV, Mermet virus; OROV, Oropouche virus; PEAV, Peaton virus; SABOV, Sabo virus; SANV, Sango virus; SATV, Sathuperi virus; SBV, Schmallenburg virus; SHAV, Shamonda virus; SHUV, Shuni virus; SIMV, Simbu virus; TINV, Tinaroo virus; THIV, Thimiri virus; YABA, Yaba-7 virus. 
Table 1. Demographic and clinical information of SHUV-positive CSF samples from 7 patients hospitalized with neurologic signs, Gauteng Province, South Africa, 2017*

\begin{tabular}{|c|c|c|c|c|c|c|c|c|}
\hline $\begin{array}{l}\text { Sample } \\
\text { ID }\end{array}$ & $\begin{array}{l}\text { Patient } \\
\text { age/sex }\end{array}$ & Other symptoms & $\begin{array}{c}\text { Clinical } \\
\text { diagnoses }\end{array}$ & HIV status & Other tests & Vaccination & $\begin{array}{c}\text { Reason for } \\
\text { discharge }\end{array}$ & Location \\
\hline $\begin{array}{l}\text { ZRUNH } \\
039 / 17\end{array}$ & $29 \mathrm{y} / \mathrm{F}$ & Not stated & Meningitis & Unknown & Not stated & Unknown & Unknown & JHB \\
\hline $\begin{array}{l}\text { ZRUNH } \\
131 / 17 \\
\end{array}$ & $\begin{array}{l}1 \text { y } 9 \\
\mathrm{mo} / \mathrm{M}\end{array}$ & Not stated & $\mathrm{TB}$, meningitis & Unknown & Not stated & Unknown & Unknown & JHB \\
\hline $\begin{array}{l}\text { ZRUNH } \\
219 / 17\end{array}$ & $6 \mathrm{mo} / \mathrm{F}$ & $\begin{array}{l}\text { Vomiting, diarrhea, } \\
\text { fine maculopapular } \\
\text { rash }\end{array}$ & $\begin{array}{c}\text { Acute } \\
\text { gastroenteritis } \\
\text { and shock }\end{array}$ & $\begin{array}{c}\text { Mother } \\
\text { (positive), on } \\
\text { HAART/ } \\
\text { PMTCT, ART } \\
\text { (FDC); baby } \\
\text { received } \\
\text { nevirapine }\end{array}$ & $\begin{array}{c}\text { H. influenzae } \\
\text { Ag (negative), } \\
\text { N. meningitidis } \\
\text { ACV W135 } \\
\text { (negative), E. } \\
\text { coli (negative), } \\
\text { S. pneumonia } \\
\text { (negative), } \\
\text { GBS } \\
\text { (negative), } \\
\text { cryptococcal } \\
\text { Ag (negative) }\end{array}$ & $\begin{array}{l}\text { Mother did not } \\
\text { have clinic } \\
\text { card }\end{array}$ & Stable & $\begin{array}{c}\text { Eastlynne, } \\
\text { Pretoria }\end{array}$ \\
\hline $\begin{array}{l}\text { ZRUNH } \\
212 / 17\end{array}$ & $\begin{array}{l}2 \text { y } 8 \\
\mathrm{mo} / \mathrm{M}\end{array}$ & $\begin{array}{l}\text { Coughing blood, } \\
\text { otitis media, simple } \\
\text { febrile seizures, } \\
\text { fever }\left(38^{\circ} \mathrm{C}\right) \text {, } \\
\text { difficulty breathing, } \\
\text { vomiting, diarrhea; } \\
\text { had second episode } \\
\text { of seizure }\end{array}$ & $\begin{array}{l}\text { Upper } \\
\text { respiratory } \\
\text { tract infection/ } \\
\text { hemoptysis/ } \\
\text { febrile } \\
\text { convulsions }\end{array}$ & $\begin{array}{c}\text { Mother } \\
\text { negative; baby } \\
\text { received } \\
\text { nevirapine }\end{array}$ & Not stated & $\begin{array}{l}\text { Up to date: } \\
\text { BGG, } \\
\text { polio+DPT } \\
\text { (3-18 mo), } \\
\text { DT (5 y) not } \\
\text { done }\end{array}$ & Stable & Pretoria \\
\hline $\begin{array}{l}\text { ZRUNH } \\
208 / 17\end{array}$ & $\begin{array}{l}4 \text { y } 11 \\
\mathrm{mo} / \mathrm{M}\end{array}$ & $\begin{array}{c}\text { Seizures, ICU } \\
\text { patient, decreased } \\
\text { LOC, vomiting, } \\
\text { seizures, fever, } \\
\text { diarrhea }\end{array}$ & $\begin{array}{l}\text { Encephalitis } \\
\text { and aspiration } \\
\text { pneumonia }\end{array}$ & Negative & $\begin{array}{l}\text { Microbiology: } \\
\text { negative for } \\
\text { bacteria }\end{array}$ & $\begin{array}{c}\text { Incomplete: } \\
\text { no polio+DPT } \\
(4,5 \mathrm{mo})\end{array}$ & Not stated & $\begin{array}{c}\text { Eastlynne, } \\
\text { Pretoria }\end{array}$ \\
\hline $\begin{array}{l}\text { ZRUNH } \\
213 / 17\end{array}$ & $13 \mathrm{~d} / \mathrm{F}$ & $\begin{array}{c}\text { ICU patient, baby } \\
\text { delivered normally, } \\
\text { neonatal } \\
\text { encephalopathy, } \\
\text { second-degree } \\
\text { congenital } \\
\text { sepsis/TORCH, poor } \\
\text { sucking, premature, } \\
\text { low birthweight, } \\
\text { nonimmune, } \\
\text { subcutaneous } \\
\text { edema, abdominal } \\
\text { distension (HC, } \\
\text { chest, AC), } \\
\text { abdominal U/S } \\
\text { (ascites, bilateral } \\
\text { dense kidneys) }\end{array}$ & $\begin{array}{l}\text { Nonimmune } \\
\text { hydrops fetalis }\end{array}$ & Not stated & $\begin{array}{l}\text { HSV (positive; } \\
\text { patient tested } \\
\text { negative } \\
\text { following } \\
\text { treatment), } \\
\text { rubella PCR } \\
\text { (IgG positive, } \\
\text { IgM negative), } \\
\text { CMV (IgG } \\
\text { positive, IgM } \\
\text { negative) }\end{array}$ & Up to date & Stable & $\begin{array}{l}\text { Mamelodi } \\
\text { East, } \\
\text { Pretoria }\end{array}$ \\
\hline $\begin{array}{l}\text { ZRUNH } \\
400 / 17 \\
{ }^{*} \mathrm{AC}, \text { abdo }\end{array}$ & $\begin{array}{l}\text { l circu } \\
\text { I-dose } \\
\text { HSV } \\
\text { ingitidi }\end{array}$ & $\begin{array}{l}\text { Respiratory distress, } \\
\text { vomiting bile } \\
\text { fference; Ag, antigen; BCC } \\
\text { sombination; GBS, group } \\
\text { herpes simplex virus; ICU } \\
\text { PMTCT, prevention of m }\end{array}$ & $\begin{array}{l}\text { Viral } \\
\text { pneumonia } \\
\text { bacille Calmett } \\
\text { treptococcus; } / \\
\text { tensive care ur } \\
\text { er-to-child tran }\end{array}$ & $\begin{array}{l}\text { érin; CMV, cy } \\
\text { Iuenzae, Hae } \\
\text {, identificatio } \\
\text { sion; SHUV, }\end{array}$ & $\begin{array}{l}\text { galovirus; DP1 } \\
\text { ilus influenzaє } \\
\text { 3, Johannesbu } \\
\text { virus; TB, tub }\end{array}$ & $\begin{array}{l}\text { theria/pertus } \\
\text { ART, highly ac } \\
\text { OC, level of c } \\
\text { sis; TORCH, }\end{array}$ & $\begin{array}{l}\text { Not stated } \\
\text { /tetanus; } E \text {. cc } \\
\text { le antiretrovira } \\
\text { sciousness; } N \\
\text { oxoplasma gor }\end{array}$ & $\begin{array}{l}\text { Olieven- } \\
\text { houtbosch, } \\
\text { Pretoria } \\
\text { Escherichia } \\
\text { therapy; } \\
\text { meningitis, } \\
\text { ii; }\end{array}$ \\
\hline
\end{tabular}

undergoing treatment. The baby of the positive mother subsequently received nevirapine. The other 2 patients were HIV negative; however, 1 of the children was given nevirapine for reasons not stated. No apparent travel history was recorded for any of these patients.

Most specimens screened were from children $(63.1 \%)$. Groups with the lowest number of patients were adolescents $(1.5 \%)$ and the elderly (4.6\%) (Table
2). There was only a slight difference in the percentage of males and female patients tested $(46.2 \%$ male and $51.7 \%$ female). A total of $6(85.7 \%)$ of 7 positive cases were in children and 1 of $7(14.3 \%)$ was in an adult. Three of the children with positive test results were $<6$ months of age. One of these positive children was a newborn admitted to the intensive care unit at 13 days of age who had not left the hospital since 
Table 2. Demographics of the patient group screened for Shuni virus, Gauteng Province, South Africa, 2017

\begin{tabular}{|c|c|c|c|}
\hline Demographic & Total no. (\%) & No. (\%) positive & Odds ratio $(95 \% \mathrm{Cl})$ \\
\hline Total & 130 & $7(5.3)$ & \\
\hline \multicolumn{4}{|l|}{ Age group, $\mathrm{y}^{*}$} \\
\hline 1 & $82(63.1)$ & $6(4.9)$ & $0.05333(0.01951-0.1458)$ \\
\hline 2 & $2(1.5)$ & $0(0)$ & 0 \\
\hline 3 & $40(30.8)$ & $0(0)$ & 0 \\
\hline 4 & $6(4.6)$ & $1(16.7)$ & $0.2(0.02337-1.71188)$ \\
\hline \multicolumn{4}{|l|}{ Sex } \\
\hline M & $60(46.2)$ & $3(42.9) \dagger$ & \\
\hline $\mathrm{F}$ & 67 (51.7) & $4(57.1) \dagger$ & \\
\hline Not stated & $3(2.3)$ & 0 & \\
\hline
\end{tabular}

birth. Aside from neurologic signs that were present in all patients, the most common recorded symptoms were vomiting, diarrhea, seizures, and fever.

SHUV was reported in horses with severe neurologic signs in South Africa during 2009-2012 (11), which prompted us to also investigate its occurrence in human cases. Screening of CSF specimens from hospitalized patients with neurologic signs around Gauteng Province in South Africa, where some of the equine cases were detected, suggests that up to $5.4 \%$ of unidentified neurologic human cases during the arbovirus season may be caused by SHUV. Six of the 7 patients who tested positive for SHUV were children $<5$ years of age, with 1 being a newborn 13 days of age; only 1 case was identified in a woman. Three of the 7 patients were discharged after being found to be stable; the outcomes of the other 4 are unknown.

These patients were also tested for other viral and bacterial infections, such as influenza, Neisseria meningitidis, pneumonia, herpes simplex virus (HSV), rubella, and cytomegalovirus (Table 1). All 7 patients showed negative results for all requested diagnostic assays except for the 13-day-old infant, who received a diagnosis of hydrops fetalis. He was IgG positive for rubella and cytomegalovirus but IgM negative for both, suggesting maternal antibody transmission. The patient was positive for HSV by PCR and was subsequently placed on treatment for 12 days postnatal until the HSV PCR yielded a negative result. Although the diagnosis of a HSV co-infection cannot rule out HSV as the cause of the hydrops fetalis, the fact that he had not left the hospital since birth suggests a likely vertical transmission of both HSV and SHUV. The patient was stable at discharge after 21 days; no death has been reported. None of the patients had any travel history, indicating that they may have been infected in or around their area of residence. Equine cases had previously been identified in these areas, suggesting possible similar vector exposure (11).
A limitation of this study was that all other potential causes of neurologic signs were not exhaustively investigated. Previous detection of SHUV in Cullicoides midges and Culex theileri mosquitoes (McIntosh BM, Epidemiology of arthropod-borne viruses in southern Africa. Unpublished thesis, University of Pretoria, 1980) suggests that SHUV has the potential to expand its geographic range and potentially emerge in new regions. The reservoir host for SHUV is not known but is thought to be ruminants and wildlife, from which transmission to humans would likely be accomplished through susceptible mosquitoes.

\section{Conclusions}

Detection of SHUV RNA in the CSF is highly suggestive of SHUV contributing to neurologic signs and likely crossing of the blood-brain barrier. However, further investigations with larger cohorts are needed to determine the disease burden of SHUV in humans across all age groups. These investigations can also include determining the geographic range, clinical presentation, potential vectors, and reservoir hosts in Africa. Improved diagnoses that include IgM serology and early PCR detection of SHUV will aid in defining the true incidence and epidemiology of SHUV.

\section{Acknowledgments}

We thank the National Health Laboratory Service of South Africa for contributing the CSF specimens and members of the Zoonotic, Arbo- and Respiratory Virus (ZARV) group at the Centre for Viral Zoonoses, Department of Medical Virology, University of Pretoria, for their assistance.

This study was funded in part through scholarships for T.P.M. by the National Research Foundation (nos. 107424 and 116385), Poliomyelitis Research Foundation (no. 17/37), and research funding from the German Federal Ministry of Education and Research (grant no.VN81204343) for the African Network for Improved Diagnostics, Epidemiology and Management of Common 
Infectious Agents - ANDEMIA, Acute Febrile Disease of Unknown Origin Project (South Africa) and the G7 Global Health Fund Program (grant no. FKZ1368-1438TO08, Strengthening of the Expertise for the Investigation of Outbreaks of Haemorrhagic Fevers and AntibioticResistant Germs [TP08], South Africa; collaboration project with Dr. F. Leendertz, Robert Koch Institute).

\section{About the Authors}

Ms. Motlou is MSc graduate at the Centre for Viral Zoonoses at the University of Pretoria, South Africa. Her primary research focused on investigating SHUV as a cause of neurological disease in humans, horses, and mosquitoes.

Dr. Venter is a molecular virologist and head of the Respiratory and Emerging Neurological Virus Research Group at the Department of Medical Virology, University of Pretoria/National Health Laboratory Services in Pretoria. Her primary research interest is the pathogenicity and epidemiology of zoonotic arboviruses, as well as viral causes of pneumonia in southern Africa.

\section{References}

1. Dash AP, Bhatia R, Sunyoto T, Mourya DT. Emerging and re-emerging arboviral diseases in Southeast Asia. J Vector Borne Dis. 2013;50:77-84.

2. Leblond A, Hendrikx P, Sabatier P. West Nile virus outbreak detection using syndromic monitoring in horses. Vector Borne Zoonotic Dis. 2007;7:403-10. https:// doi.org/10.1089/ vbz.2006.0593

3. Drummond R. Surveillance for West Nile virus in horses. Vet Rec. 2008;162:763. https://doi.org/10.1136/vr.162.23.763-a

4. Venter M, Pretorius M, Fuller JA, Botha E, Rakgotho M, Stivaktas $\mathrm{V}$, et al. West Nile virus lineage 2 in horses and other animals with neurologic disease, South Africa, 2008-2015. Emerg Infect Dis. 2017;23:2060-4. https://doi.org/10.3201/eid2312.162078

5. Zaayman D, Venter M. West Nile virus neurologic disease in humans, South Africa, September 2008-May 2009. Emerg Infect Dis. 2012;18:2051-4. http:/ /dx.doi.org/10.3201/eid1812.111208
6. Archer BN, Thomas J, Weyer J, Cengimbo A, Landoh DE, Jacobs $\mathrm{C}$, et al. Epidemiologic investigations into outbreaks of Rift Valley fever in humans, South Africa, 2008-2011. Emerg Infect Dis. 2013;19:1918-25. https:/ / dx.doi. org/10.3201/eid1912.121527

7. Budasha NH, Gonzalez J-P, Sebhatu TT, Arnold E. Rift Valley fever seroprevalence and abortion frequency among livestock of Kisoro district, South Western Uganda (2016): a prerequisite for zoonotic infection. BMC Vet Res. 2018;14:271. https:/ / doi.org/10.1186/s12917-018-1596-8

8. Baudin M, Jumaa AM, Jomma HJE, Karsany MS, Bucht G, Näslund J, et al. Association of Rift Valley fever virus infection with miscarriage in Sudanese women: a crosssectional study. Lancet Glob Health. 2016;4:e864-71. https:/ / doi.org/10.1016/S2214-109X(16)30176-0

9. Reynolds ES, Hart CE, Hermance ME, Brining DL, Thangamani S. An overview of animal models for arthropod-borne viruses. Comp Med. 2017;67:232-41.

10. Venter $\mathrm{M}$. The role of zoonotic vector borne viruses as neurological pathogens in horses in South Africa. Annual South African Equine Veterinary Association Congress; Limpopo, South Africa, February 13-17, 2011.

11. van Eeden C, Williams JH, Gerdes TG, van Wilpe E, Viljoen A, Swanepoel R, et al. Shuni virus as cause of neurologic disease in horses. Emerg Infect Dis. 2012;18:31821. https://doi.org/10.3201/eid1802.111403

12. Golender N, Bumbarov V, Assis I, Beer M, Khinich Y, Koren $\mathrm{O}$, et al. Shuni virus in Israel: neurological disease and fatalities in cattle. Transbound Emerg Dis. 2019;66:1126-31. https://doi.org/10.1111/tbed.13167

13. Causey OR, Kemp GE, Causey CE, Lee VH. Isolations of Simbu-group viruses in Ibadan, Nigeria 1964-69, including the new types Sango, Shamonda, Sabo and Shuni. Ann Trop Med Parasitol. 1972;66:357-62. http://dx.doi.org/10.1080/ 00034983.1972.11686835

14. Steyn J, Motlou P, van Eeden C, Pretorius M, Stivaktas VI, Williams J, et al. Shuni virus in wildlife and non-equine domestic animals, South Africa. Emerg Infect Dis. 2020;26:1521-5. https://doi.org/10.3201/eid2607.190770

15. Hall TA. BioEdit: a user-friendly biological sequence alignment editor and analysis program for Windows 95/98/ NT. Nucleic acids symposium series. London: Information Retrieval Ltd., 1999. p. 95-8.

Address for correspondence: Marietjie Venter, University of Pretoria, Pretoria, South Africa; email: marietjie.venter@up.ac.za 